\title{
Effect of the pulsation type (alternate or simultaneous) on milk yield and health status of the mammary gland of Murciano-Granadina goats
}

\author{
J. Bueso-Ródenas, ${ }^{1}$ G. Romero, ${ }^{2}$ A. Navarro, ${ }^{2}$ E. Pérez, ${ }^{2}$ and J. R. Díaz ${ }^{2 *}$ \\ ${ }^{1}$ Dpto. Producción Animal y Salud Pública, Universidad Católica de Valencia (UCV), C/Guillem de Castro 94, 46001 Valencia, Spain \\ ${ }^{2}$ Dpto. Tecnología Agroalimentaria, Universidad Miguel Hernández (UMH), Ctra. de Beniel km 3.2., 03312 Orihuela (Alicante), Spain
}

\begin{abstract}
Recent research into how the pulsation type affects goat milking concluded that alternate pulsation (AP) and simultaneous pulsation (SP) similarly affect the milking efficiency (milking duration and milking fractioning) and teat end condition after milking when both pulsations are employed in short-term experiments. However, the use of SP in high pipeline milking machines led to higher vacuum fluctuations, which, in the long term, may entail a potential risk factor for the mammary gland health status. The aim of this work was to study how AP and SP affect the milk yield, mammary gland health status, and milk composition of goats in the long term, during a complete lactation period, in a high pipeline milking machine. With this objective, 100 Murciano-Granadina goats with similar parturition dates ( $4 \pm 1$ postpartum weeks) were divided into 2 similar groups (50 goats per group) according their parity, milk yield, mammary gland health status, and milking duration (after a 15-d pre-experimental period). Throughout the experimental period $(7 \mathrm{mo})$, one group was milked using SP and the other group using AP. Every month, samplings were carried out of the variables related to sanitary status of the mammary gland, milk fractioning, milking duration, average and maximum milk flows, milk composition, teat end status, vacuum fluctuations at the short milk tube during milking, and pulsation tests. Results showed that the use of $\mathrm{SP}$ in a high pipeline milking machine showed higher vacuum fluctuations without involving any difference in the other variables studied. We concluded that the use of AP in the milking of Murciano-Granadina goats offers little improvement of the milking performance and increases the investment required for installation and maintenance of the milking machines.
\end{abstract}

Received June 27, 2018.

Accepted December 17, 2018.

*Corresponding author: jr.diaz@umh.es
Key words: milking, dairy goat, udder health, teat condition

\section{INTRODUCTION}

Historically, in milking parlors for cows, the design of the pulsation system meant that milking and massage pulsation chamber phases had to run simultaneously at 4 teat cups of each milking unit (Bueso-Ródenas et al., 2016). This pulsation type is designated 4 by 0 pulsation or simultaneous pulsation (SP). Pulsators that are more modern allow 2 teat cups to be in milking phase at the same time as the other 2 are in massage phase; this is called 2 by 2 pulsation or alternate pulsation (AP). This technology has recently been adapted to small ruminant milking machines, so dairy operators can choose between 2 types of pulsation, AP or SP.

Most developers of milking technologies for dairy cows have moved from SP to AP, although independent research works on its benefits are scarce. In a literature review, we found no works that directly compared both types of pulsation in a long-term study, which would be mandatory to test the effects on milk production and composition and udder health. McDonald and Witzel (1968) found that SP showed higher vacuum fluctuations at the teat end than AP. More recent studies carried out in dairy cows (Gleeson et al., 2004; O'Callaghan, 2004) compared milking systems differing not only in the type of pulsation but also in characteristics of the liners and volume of the claw. A reduction in the milking duration and vacuum fluctuations at the teat end were observed by Gleeson et al. (2004) and by O'Callaghan (2004), respectively, when the AP was used. However, in those works, no differences were found in teat tissue changes after machine milking or in milk yield between pulsation types.

In a recent bibliographic search, no research works were found regarding the different types of pulsation on dairy ewes. Billon (2004) stated that there are no technical reasons for using AP for dairy ewes with modern clusters and liners (similar average, minimum and 
maximum teat end vacuum, and similar movement of the liner). Billon (2004) also noted that the only reason for choosing AP in dairy sheep milking machines would be when using very small clusters with a small internal diameter of the short milk tubes to avoid claw flooding by dividing the milk flow rate by 2 . In any case, we have to take into account that these experiments were performed in a low pipeline milking machine, as there were no mentions of the possible different effects of the type of pulsation depending on different milking pipeline heights.

In a recent research on how the type of pulsation affects goat milking, Bueso-Ródenas et al. (2016) carried out a short-term study on milking performance of Alpine goats milked using AP and SP at 2 different system vacuum levels (38 and $42 \mathrm{kPa}$ ) in a low-line milking machine. Results showed that the use of AP reduced the vacuum fluctuations and increased the average vacuum in the short milk tube. Moreover, when a level of $42 \mathrm{kPa}$ was set, the use of AP reduced the milking duration. Those authors concluded that the use of AP could offer some advantages compared with SP in conditions of high milk flow or when milk flow can occupy the entire section of the short milk tube, as in milking with high vacuum level. This research group performed another study (Romero et al., 2017) on Murciano-Granadina goats using AP and SP in short-term experiments at high and low milk pipeline heights. Their findings showed that AP and SP similarly affected the milk yield and fractioning and milking duration and teat end condition when both pulsations were studied in both high and low pipeline heights. Additionally, as observed by Billon (2004), vacuum fluctuations showed no differences between both types of pulsation when low line was used. Nevertheless, higher vacuum fluctuations were obtained with SP in high line in both studies compared with AP.

The effect of vacuum fluctuations has been discussed in many research works, as reported by Besier et al. (2016). Certain means of transmission of pathogen agents between animals, such as reverse flow, impacts, or reverse pressure gradients, are related to the changes in vacuum level in the short milk tubes during milking (Rasmussen et al., 1994; Billon et al., 1998). However, in small ruminants, the effects of vacuum fluctuations have not been fully explained. It is assumed, as explained in dairy cows, that fluctuations have potential to worsen mammary gland health status; however, some studies in goats (Manzur et al., 2012; Romero et al., 2015) showed significant vacuum fluctuations (up to $12.4 \mathrm{kPa}$, calculated as maximum minus minimum vacuum) with no effect on the mammary gland health status.
Taking into account the previous results in the shorttime research (Romero et al., 2017), this experiment was designed to study how AP and SP affect milk yield, milk composition, and teat end condition of MurcianoGranadina goats during a complete lactation period. In addition, we tested whether the higher vacuum fluctuations obtained in high line with SP can affect the mammary gland health status compared with AP.

\section{MATERIALS AND METHODS}

\section{Facilities and Animal Handling}

The experiments were carried out at the research and teaching farm of the Escuela Politécnica Superior de Orihuela (Universidad Miguel Hernández de Elche). The farm contains 240 Murciano-Granadina goats managed in 2 kidding groups (one in September and the other in March). The average weight of the goats was $50 \mathrm{~kg}$; parity ranged from 1 to 5 . Goats during lactation were fed twice a day with $1,500 \mathrm{~g} / \mathrm{d}$ per animal of cereal mixture (corn $23 \%$, barley $21 \%$, dried beet pulp $14 \%$, hulled oats $13 \%$, soybean meal $9.2 \%$, peas $8 \%$, sunflower seeds $3.3 \%$, sunflower meal $3 \%$, dried orange pulp $4.8 \%$, salt $0.4 \%$, and soybean oil $0.3 \%$ ) and 1,000 $\mathrm{g} / \mathrm{d}$ per animal of alfalfa hay. Straw and water were offered ad libitum. Goats during lactation had free access to confined sunny areas but no access to pasture. A GeaFarm Technologies (Bönen, Germany) high-line (150 cm upper milking platform) milking machine in a side-by-side type $1 \times 12 \times 12$ milking parlor was used. The parlor was equipped with a new generation pulsator (StimoPuls Apex M, GeaFarm Technologies), allowing us to switch between AP and SP electronically. The milking units were equipped with TopFlow teat cups (GeaFarm Technologies), 10-mm internal diameter short milk tubes, 2-m-long milk tubes with internal diameter of $14 \mathrm{~mm}$, and $40-\mathrm{mL}$ claw bowls (GeaFarm Technologies). Milking parameters were system vacuum of $40 \mathrm{kPa}$, pulsation rate of 90 cycles/min, and pulsation ratio of 60:40. Milking was carried out once a day, as is usual in this breed in southeastern Spain, at $0900 \mathrm{~h}$.

\section{Experimental Design}

Pre-Experimental Period. A pre-experimental period of $15 \mathrm{~d}$ was included to select the animals that would be included in the study and determine their initial condition. A first sampling was performed in a group of 120 goats with similar parturition dates (4 \pm 1 postpartum weeks) in which milking fractioning, milking duration, and health status of the mammary gland were recorded. From the results, 100 goats with 
milk yield higher than $0.75 \mathrm{~kg}$, milking duration shorter than $6 \mathrm{~min}$, and free of clinical mastitis were selected. The selected animals were randomly distributed into 2 groups of 50 animals according to parity, milk yield, mammary gland health status, and milking duration.

During the pre-experimental period, all the animals were milked with SP and the milking units were removed manually, based on the judgment of an experienced milker. In this period, 4 samplings were respectively performed on 4 different and nonconsecutive days following this sequence: (d 1) sanitary status of the mammary gland; (d 2) efficiency of milking (milking duration and milking fractioning), milk composition, and SCC; (d 3) teat end status; and (d 4) vacuum levels during milking.

Experimental Period. The experimental period lasted 7 mo, during which each group of animals was milked according to milking conditions (SP or AP) that were assigned at the beginning of this period. Every month, over $8 \mathrm{~d}$, 4 samplings were performed on 4 nonconsecutive days, following the same sequence performed in the pre-experimental period.

The milking routine was similar in the 2 treatments tested and included cluster attachment, machine milking, machine stripping, and manual cluster removal at the end of the milking. If a teat cup falloff was observed during milking, it was immediately reattached. Finally, teats were immersed in an iodine solution (Proactive, DeLaval, Tumba, Sweden).

\section{Variables Analyzed}

Sanitary Status of the Mammary Gland. The health status of the mammary gland was evaluated through bacteriological analysis and SCC of each mammary gland using milk samples obtained before milking. For bacteriological analysis, foremilk was discarded, the teats were cleaned with $70 \%$ alcohol, and 5 -mL samples of milk from each gland were taken. Samples were kept at $4^{\circ} \mathrm{C}$ for up to $4 \mathrm{~h}$ until bacteriological analysis. Bacteriological analysis was performed by seeding $20 \mu \mathrm{L}$ of milk in blood agar plates (5\% sheep blood, Biomerieux, Lyon, France). The plates were incubated aerobically at $37^{\circ} \mathrm{C}$ and examined at 24,48 , and $72 \mathrm{~h}$. Microbiological cultures showing 5 or more identical colonies were considered positive. For SCC analysis, 50-mL samples of milk were taken by hand and azidiol was added to them. The SCC $\left(\times 10^{3}\right.$ cells $\left./ \mathrm{mL}\right)$ per gland was analyzed at the interprofessional dairy laboratory (LICOVAL, Valencia, Spain) by the fluoro-opto-electronic method (Schmidt-Madsen, 1975) using a Fossomatic 5000 device (Foss, Hillerød, Denmark).
Classification of the sanitary status of the mammary glands followed the system of Díaz et al. (2011). We determined that a gland showed IMI when the bacteriological analysis was positive. When the bacteriological analysis was negative but the SCC exceeded 1,500,000 cells $/ \mathrm{mL}$, it was considered unspecific mastitis. If the bacteriological analysis was negative and the SCC exceeded 1,500,000 cells/mL in both mammary glands from only 1 sampling and returned to normal values in the following sampling, it was considered not to be due to pathological causes and was classified as free of mastitis. Finally, animals were classified as mastitisfree when both mammary glands had this condition.

Efficiency of Milking, Milk Composition, and SCC of Obtained Milk. Milking routine during a sampling day included attaching the teat cups, machine milking (recording of machine milk, average and maximum milk flows, and milking duration), manual teat cup detachment, hand stripping (recording handstripping milk), and recording of residual milk after application of $4 \mathrm{IU}$ of oxytocin (Dalmatocina, Fatro Ibérica, Barcelona, Spain). Finally, teats were immersed in an iodine solution.

Machine milk (kg) was the amount milked in the period from teat cup attachment to teat cup detachment, carried out by an experienced milker. Machine milk and, additionally, the variables average and maximum milk flows $(\mathrm{kg} / \mathrm{min})$ during the main milking phase were registered using 6 Lactocorder devices (Lactocorder, Balgach, Switzerland). Milking duration (min) was the time required to obtain machine milk and was registered using a digital chronometer (HS-70W, Casio, Tokyo, Japan). Hand-stripping milk (g) and residual milk (g) were weighed with a digital device with \pm 1 g precision (BC-200, Fagor, Oñati, Spain). Total milk obtained $(\mathrm{kg})$ was the result of the sum of machine milk, hand-stripping milk, and residual milk.

Lactocorder devices were set to obtain $50 \mathrm{~mL}$ of milk from the milking of each animal to analyze milk composition and SCC per animal. With this aim, on the same day, a subsample of $25 \mathrm{~mL}$ was analyzed by a MilkoScan FT 120 device (Foss). Milk composition included its content in fat, protein, lactose, and DM, expressed as a percent of wet matter. With the other subsample of 25 $\mathrm{mL}$, the SCC $\left(\times 10^{3}\right.$ cells $\left./ \mathrm{mL}\right)$ per animal was analyzed at the interprofessional dairy laboratory (LICOVAL) using the same method described below.

Teat End Status. To study the teat end status of the goats, a portable ultrasound device (Agroscan AL, ECM, Noveko International Inc., Angoulême, France) was used. Ultrasound scans of the right teat of each animal were performed before and after milking with 


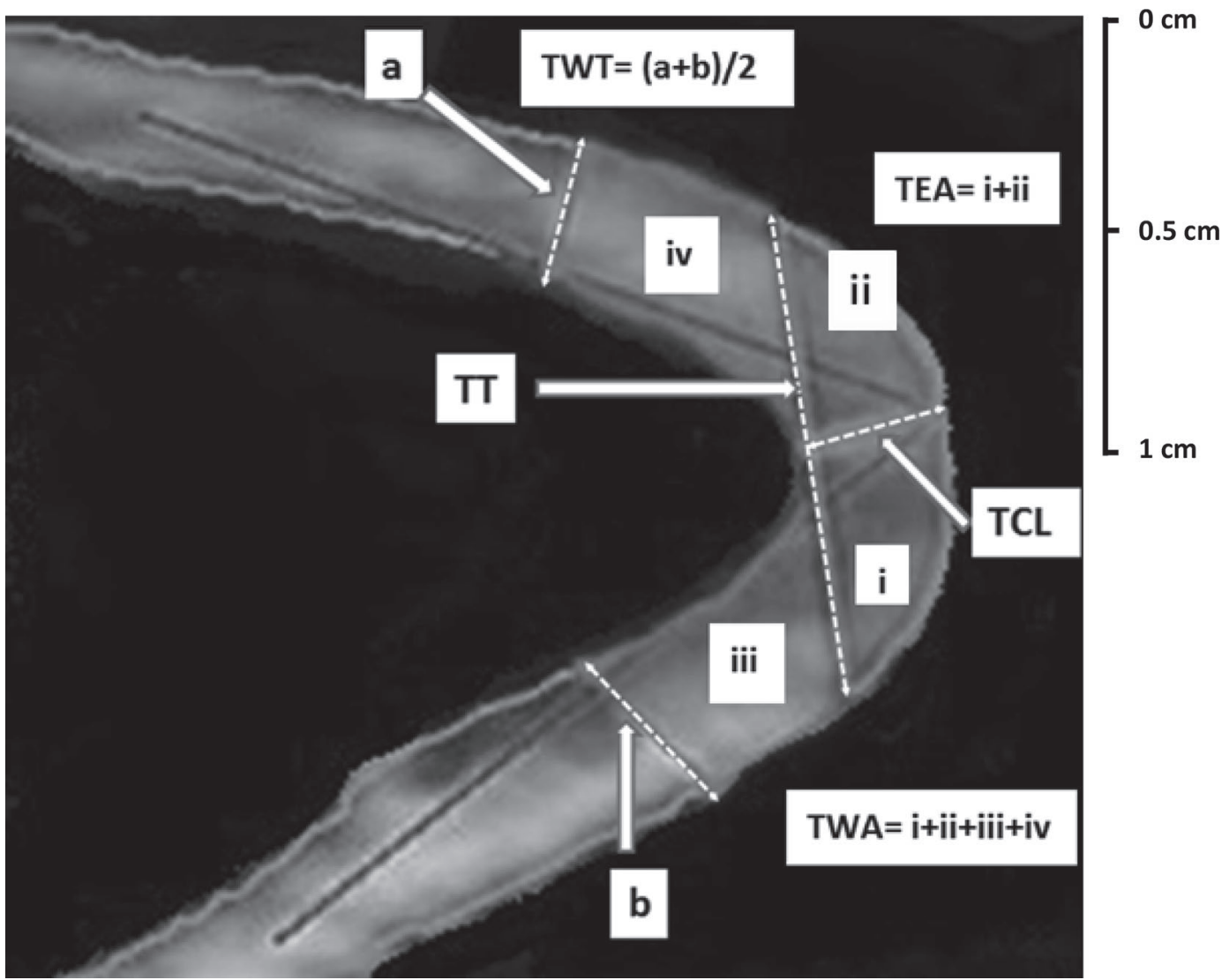

Figure 1. Frame of the sagittal plane of the teat end carried out with ultrasound scan at the right teat of each animal. TWT $=$ teat wall thickness, $\mathrm{cm}$; TT = teat thickness, $\mathrm{cm}$; TCL $=$ teat canal length, $\mathrm{cm} ; \mathrm{TEA}=$ teat end area, $\mathrm{cm}^{2} ; \mathrm{TWA}=$ teat wall area, $\mathrm{cm}^{2}$.

a linear probe at $5 \mathrm{MHz}$ frequency and $8 \mathrm{~cm}$ depth, according to the methodology of Díaz et al. (2013). The sonographic images obtained were recorded and digitally scanned with Real DVD Studio Gold software (NPG Technology, Madrid, Spain). Later, video editing software (Ulead Video Studio, Corel, Ottawa, Canada) was used to take a frame of the sagittal plane of the teat end at the level of the teat sphincter. Finally, another software suite (Ecopezón, Universidad Miguel Hernández de Elche) was used to measure variables. (1) Teat wall thickness $(\mathrm{cm})$ was measured by 2 lines (lines A and B) traced along the middle axis of the 2 teat walls; at $1 \mathrm{~cm}$, a perpendicular line was drawn measuring the width of each wall (upper and lower) to obtain the mean value of both measurements. (2) Teat thickness $(\mathrm{cm})$ was the distance between both sides of the teat in a section at the level of the inner of the teat canal. (3) Teat end area $\left(\mathrm{cm}^{2}\right)$ was the area from the inner to the outer end of the teat canal. (4) Teat wall area $\left(\mathrm{cm}^{2}\right)$ was measured as the area covering both walls (upper and lower) to a distance of $1 \mathrm{~cm}$ from the teat end, including the teat end area. (5) Teat canal length $(\mathrm{cm})$ was distance from the inside to the outside of the teat canal (Figure 1). From the values recorded in the scans before the cluster attachment and after their removal, the percentage increase of each variable was computed according to the formula

Increase $\%=[($ value after milking

- value before milking)/value before milking)] $\times 100$.

In this way, we calculated increase in teat wall thickness (ITWT, \%), increase in teat thickness (ITT, \%), increase in teat wall area (ITWA, \%), increase in teatend area (ITEA, \%), and increase in teat canal length (ITCL, \%).

Vacuum Level and Pulsation Test Variables. The variables related to the variation of vacuum level were recorded using Pulsotest Comfort (GeaFarm Technologies) device (response rate of $1,500 \mathrm{kPa} / \mathrm{s}$ when directly connected to the pulsator; Rasmussen et al., 2003) and set at a sampling rate frequency of $166.7 \mathrm{~Hz}$. Every month, 20 vacuum level measurements and 20 
pulsation tests within each of the groups were recorded in random goats. The vacuum level measurements were performed in the short milk tubes. The variables recorded were maximum vacuum level $(\mathrm{kPa})$, average vacuum level $(\mathrm{kPa})$, and minimum vacuum level $(\mathrm{kPa})$. From the values of maximum vacuum level and minimum vacuum level, vacuum fluctuation (maximum vacuum level - minimum vacuum level, $\mathrm{kPa}$ ) was calculated. During the pulsation tests, average pulsation ratio (\%) and limping (\%) were recorded.

\section{Statistical Analysis}

Variable SCC per animal was transformed (LSCC; $\log 10$ SCC) to achieve normality of distribution (Ali and Shook, 1980). To determine the initial characteristics of the 2 groups of animals included in the experiment, a general linear model (Proc GLM; SAS Institute Inc., 2012) was employed on the values of the pre-experimental period of the dependent variables related to (1) milking efficiency (machine milk, milking duration, hand-stripping milk, residual milk, and total milk obtained); (2) milk composition (fat, protein, lactose, and DM); and (3) teat-end status (ITWT, ITT, ITWA, ITEA, and ITCL) and LSCC, considering each group of animals ( 1 and 2 ) as a factor.

A linear mixed model (Proc GLIMMIX; SAS Institute Inc., 2012) was used to determine the effect of the treatments on the variables related to (1) milking efficiency (machine milk, milking duration, average milk flow, maximum milk flow, hand-stripping milk, residual milk, and total milk obtained); (2) milk composition (fat, protein, lactose, and DM); and (3) teat end status (ITWT, ITT, ITWA, ITEA, and ITCL) and LSCC. Fixed effects included treatment (2 levels: SP and AP), month of lactation (7 levels: $1-7)$, and their respective pre-experimental covariables (values of each variable recorded in the pre-experimental period). For milking duration, the machine milk was added as covariable. The effects of mammary gland sanitary status (3 levels: IMI, unspecific mastitis, mastitis-free), parity (6 levels: 1-6), the interaction between treatment and month of lactation, and the interaction between treatment and parity were not included in the final model, as they were not significant.

In all models, the animal was considered as a random term, and a compound symmetry covariance structure was used to consider repeated measures over time in the same animal. The model using this hierarchical structure provided the best fit for the data when compared with different models considering other covariance and hierarchical structures (as assessed using Bayesian and Akaike information criteria).
To study the association of the treatments (AP and SP) with the number of new cases of mastitis, Chisquare values (Proc Freq.; SAS Institute Inc., 2012) were computed. Finally, a general linear model (Proc GLM; SAS Institute Inc., 2012) was employed to study the association of each treatment (AP and SP) with the maximum vacuum level, minimum vacuum level, average vacuum level, vacuum fluctuation, average pulsation ratio, and limping, considering treatment as factor.

\section{RESULTS AND DISCUSSION}

Analysis of the values from the pre-experimental period of the dependent variables related to milking efficiency (milking duration, machine milk, average milk flow, maximum milk flow, hand-stripping milk, and residual milk), milk composition (fat, protein, lactose, and DM), teat end status (ITWT, ITT, ITWA, ITEA, and ITCL), and LSCC showed that, initially, no significant differences existed between the 2 groups studied in the experiment (Table 1).

Most of the variables related to milking efficiency (machine milk, milking duration, average milk flow, maximum milk flow, residual milk, and total milk obtained) were affected by their pre-experimental values (covariate) and the month of lactation $(P<0.01)$. As an exception, the values of hand-stripping milk were also affected by pre-experimental values, but not by the month of lactation. In no case were the variables related to milking efficiency (milking duration and milk fractioning) affected by the treatment applied. Thus, in both groups of goats, lower values of these variables were observed as lactation progressed, whereas handstripping milk was stable throughout lactation.

The variables related to milk composition, fat, protein, lactose, and DM were affected by their preexperimental values and the month of lactation $(P<$ 0.01 ), but not by the treatment. The SCC variable was not affected by the treatment $(F=0.13 ; P=0.72)$ and remained low in both groups of animals throughout the experimental period (AP obtained 426,000 cells/mL and SP obtained 457,000 cells/mL; Table 2). Moreover, the number of new cases of mastitis during lactation was low and not related to the treatment applied (AP: 2 animals in the second month and 2 animals in the sixth month; SP: 2 animals in the second month, 1 animal in the third month, and 2 animals in the sixth month).

Variables related to teat end status were affected by the month of lactation and, with the exception of ITWT and ITCL, were also affected by the values in the pre-experimental period sampling. Similar to what was 
observed in the variables related to milking efficiency (milking duration and milking fractioning), we found no effect of the treatment on the values of the teat-end status. Thus, again, lower values of these variables were observed as lactation progressed.

Regarding the variables related to the vacuum level in the milk short tubes, we noted no effect of the treatment on maximum vacuum level and average vacuum level. However, minimum vacuum level was lower $(P$ $<0.01$, Table 2) when simultaneous pulsation was applied. This result meant that simultaneous pulsation showed higher vacuum fluctuations (differences of 3.3 $\mathrm{kPa}$ ) compared with AP. Regarding average pulsation ratio and limping, no effects of the treatment were observed on these variables.

Milk yield of the 2 groups of goats was slightly better than that found in previous studies with similar milking parameters (system vacuum of $40 \mathrm{kPa}$, pulsation rate of 90 cycles/min, and pulsation ratio of 60:40) in Murciano-Granadina goats during a complete lactation period (Romero et al., 2015). This could be due to several factors, such as differences in sanitary status of the mammary gland (similar SCC but different prevalence of IMI, 11 vs. 14\%), the kidding season (spring vs. autumn), or the number of primiparous or multiparous goats in both studies (12/50 vs. $12 / 32$ for primi- vs. multiparous, respectively).
As observed in short-term experiments carried out by this research group (Romero et al., 2017), the use of a different type of pulsation, SP or AP, did not affect results of the variables related to milking efficiency (machine milk, hand-stripping milk, residual milk, average milk flow, maximum milk flow, and milking duration) and teat end status. The absence of differences in milking duration and average vacuum level in the short milk tube between both types of pulsation agree with results observed in the teat end condition variables. Thus, similar time of exposure of the teat end to a similar level of vacuum led to a similar teat end congestion or edema after milking; this has also been observed in other works carried out with dairy cows (Hamann et al., 1994) and sheep (Alejandro et al., 2014). On the other hand, as observed in high line milking installations (Romero et al., 2017), the use of SP led to higher vacuum fluctuations than AP. The explanation of this phenomenon is that, during SP, the simultaneous occurrence of the milking phase of both teat cups in the milking unit can collapse the short milk tube and claw and ease the occurrence of duct blocking, which causes vacuum fluctuations (Osterås and Lund, 1980; Díaz et al., 2004; Ambord and Bruckmaier, 2010). Nevertheless, in the present case, vacuum fluctuations in SP did not involve a decrease in the milk emission, agreeing with the lack of sig-

Table 1. Initial characteristics of the 2 groups of animals included in the experiment on milk fractioning, milking duration, milk composition, sanitary status of the mammary gland, and teat end status (means $\pm \mathrm{SE}$ )

\begin{tabular}{lccc}
\hline Variable & Group 1 & Group 2 & SL $^{1}$ \\
\hline Goats (no.) & 50 & 50 & - \\
$\quad$ Multiparous & 38 & 38 & - \\
Primiparous & 12 & 12 & - \\
Machine milk (kg) & $2.85 \pm 0.12$ & $2.89 \pm 0.12$ & $\mathrm{NS}^{2}$ \\
Hand-stripping milk (g) & $118 \pm 0.12$ & $126 \pm 0.12$ & NS \\
Residual milk (g) & $154 \pm 28$ & $91 \pm 28$ & NS \\
Total milk (kg) & $3.12 \pm 0.13$ & $3.10 \pm 0.13$ & NS \\
Milking duration (min) & $4.05 \pm 0.22$ & $3.92 \pm 0.22$ & NS \\
Average milk flow (kg/min) & $0.61 \pm 0.05$ & $0.66 \pm 0.05$ & NS \\
Maximum milk flow (kg/min) & $0.93 \pm 0.07$ & $0.98 \pm 0.07$ & NS \\
Fat (\%) & $3.71 \pm 0.20$ & $3.70 \pm 0.20$ & NS \\
Protein (\%) & $3.26 \pm 0.08$ & $3.32 \pm 0.08$ & NS \\
Lactose (\%) & $4.28 \pm 0.06$ & $4.36 \pm 0.06$ & NS \\
DM (\%) & $11.75 \pm 0.21$ & $11.88 \pm 0.21$ & NS \\
Log SCC & $2.28 \pm 0.04$ & $2.26 \pm 0.04$ & NS \\
SCC ( $\times 10^{3}$ cells/mL) & 188 & 182 & - \\
MASTC (no.) & 5 & 6 & NS \\
UNMAST (no.) & 1 & 0 & NS \\
Variation of teat wall thickness (\%) & $71.5 \pm 8.5$ & $80.4 \pm 9.2$ & NS \\
Variation of teat wall area (\%) & $40.8 \pm 6.1$ & $44.1 \pm 7.1$ & NS \\
Variation of teat end area (\%) & $129.7 \pm 16.4$ & $119.1 \pm 14.5$ & NS \\
Variation of teat thickness (\%) & $30.2 \pm 3.2$ & $35.1 \pm 4.8$ & NS \\
Variation of teat canal length (\%) & $91.8 \pm 8.9$ & $80.5 \pm 7.5$ & \\
\hline
\end{tabular}

${ }^{1} \mathrm{SL}=$ significance level.

${ }^{2}$ MASTC $=$ incidence of subclinical mastitis at the beginning of the experiment.

${ }^{3} \mathrm{UNMAST}=$ incidence of unspecific mastitis at the beginning of the experiment. 
nificant differences in average milk flow and average vacuum level.

The first conclusion of Romero et al. (2017) was that more long-term studies with complete lactation periods were needed to determine how AP and SP affect production and milk composition. In the present study, the use of SP or AP did not result in differences in milk production or milk composition. As observed in other works during a complete lactation in goats (Romero et al., 2015), the optimal emptying of the mammary gland observed in both groups of animals of the present study (percentage of milk remaining in the udder after cluster detachment was less than 10\%) implied a good persistence of milk synthesis throughout lactation. Another factor related to the absence of differences in milk production was the similar sanitary status of the mammary gland found in both groups throughout lactation, a result that has been observed in several experiments in goats and ewes (Goetsch et al., 2011; Arias et al., 2012). Milk composition variables were similar in both groups of animals. It seems that, in the absence of changes in the sanitary status of the mammary gland or in the milking efficiency (milking duration and milking fractioning), different milking parlor designs or changes of the milking parameters do not affect milk composition (Manzur et al., 2012; Romero et al., 2015).

The second conclusion of Romero et al. (2017) was that it was necessary to test whether the higher vacuum fluctuations obtained in a high line with $\mathrm{SP}$ can affect the mammary gland health status compared with AP. In the present study, again, the use of SP led to higher vacuum fluctuations than AP. Currently, in small ruminants, it is difficult to establish a base threshold for the level of vacuum fluctuations whereby these phenomena could worsen the sanitary status of the mammary gland. In fact, no research in goats directly relates vacuum fluctuations and mammary gland health status, unlike in cows (Billon et al., 1998). In any case, Mein et al. (2004) reported that regular vacuum fluctuations could not be responsible for worse udder health values if there were not also pulsation failures, liner slips, or intense machine stripping. More-

Table 2. Effect of the different treatments applied (means \pm SE) on milking efficiency (milking duration and milking fractioning), milk composition, sanitary status of the mammary gland, teat end status, and vacuum levels

\begin{tabular}{|c|c|c|c|}
\hline Variable & $\begin{array}{l}\text { Alternate } \\
\text { pulsation }\end{array}$ & $\begin{array}{l}\text { Simultaneous } \\
\text { pulsation }\end{array}$ & $\mathrm{SL}^{1}$ \\
\hline Machine milk (kg) & $2.19 \pm 0.05$ & $2.14 \pm 0.05$ & NS \\
\hline Hand-stripping milk (g) & $107 \pm 6$ & $94 \pm 6$ & NS \\
\hline Residual milk (g) & $113 \pm 8$ & $112 \pm 8$ & NS \\
\hline Total milk (kg) & $2.39 \pm 0.05$ & $2.34 \pm 0.05$ & NS \\
\hline Milking duration (min) & $4.49 \pm 0.12$ & $4.22 \pm 0.12$ & NS \\
\hline Average milk flow $(\mathrm{kg} / \mathrm{min})$ & $0.57 \pm 0.03$ & $0.57 \pm 0.03$ & NS \\
\hline Maximum milk flow $(\mathrm{kg} / \mathrm{min})$ & $0.82 \pm 0.05$ & $0.81 \pm 0.05$ & NS \\
\hline Fat $(\%)$ & $4.66 \pm 0.07$ & $4.64 \pm 0.07$ & NS \\
\hline Protein (\%) & $3.88 \pm 0.04$ & $3.75 \pm 0.04$ & NS \\
\hline Lactose (\%) & $4.04 \pm 0.02$ & $4.05 \pm 0.02$ & NS \\
\hline $\mathrm{DM}(\%)$ & $13.15 \pm 0.11$ & $12.97 \pm 0.11$ & NS \\
\hline $\log _{10} \mathrm{SCC}$ & $2.63 \pm 0.07$ & $2.66 \pm 0.07$ & NS \\
\hline SCC $\left(\times 10^{3}\right.$ cells $\left./ \mathrm{mL}\right)$ & 426 & 457 & - \\
\hline MASTNC $^{2}$ (no.) & 4 & 5 & NS \\
\hline $\mathrm{UNMAST}^{3}$ (no.) & 0 & 0 & NS \\
\hline Variation of teat wall thickness (\%) & $50.70 \pm 3.14$ & $56.28 \pm 3.26$ & NS \\
\hline Variation of teat wall area $(\%)$ & $28.75 \pm 2.04$ & $32.14 \pm 2.11$ & NS \\
\hline Variation of teat end area (\%) & $85.19 \pm 5.54$ & $95.21 \pm 5.74$ & NS \\
\hline Variation of teat thickness (\%) & $16.20 \pm 1.33$ & $18.81 \pm 1.39$ & NS \\
\hline Variation of teat canal length (\%) & $70.15 \pm 4.48$ & $80.09 \pm 4.64$ & NS \\
\hline Maximum vacuum level (kPa) & $39.0 \pm 0.4$ & $38.9 \pm 0.5$ & NS \\
\hline Minimum vacuum level ( $\mathrm{kPa})$ & $33.5 \pm 0.4^{\mathrm{a}}$ & $30.1 \pm 0.5^{\mathrm{b}}$ & $*$ \\
\hline Average vacuum level (kPa) & $35.0 \pm 0.4$ & $34.5 \pm 0.4$ & NS \\
\hline Vacuum fluctuation $(\mathrm{kPa})$ & $5.5 \pm 0.3^{\mathrm{a}}$ & $8.8 \pm 0.5^{\mathrm{b}}$ & $*$ \\
\hline Average pulsation ratio (\%) & $60.3 \pm 0.04$ & $60.2 \pm 0.21$ & NS \\
\hline Limping $^{4}(\%)$ & $0.2 \pm 0.04$ & $0.2 \pm 0.07$ & NS \\
\hline
\end{tabular}

${ }^{\mathrm{a}, \mathrm{b}}$ Values in the same row with different letters differ at $P<0.05$.

${ }^{1} \mathrm{SL}=$ significance level.

${ }^{2}$ MASTC $=$ incidence of subclinical mastitis at the beginning of the experiment.

${ }^{3}$ UNMAST $=$ incidence of unspecific mastitis at the beginning of the experiment.

${ }^{4}$ Limping $=$ the difference between pulsation ratios measured on the 2 short pulsation tubes.

$* P<0.05$. 
over, recently, Besier et al. (2016) stated that even irregular or cyclic vacuum fluctuations per se seem not to have any negative affect; rather, the combination of several parameters, such as the simultaneous existence of irregular and regular vacuum fluctuations at high vacuum levels and long machine-on times or overmilking, are responsible for the occurrence of udder infection, edema, or hyperkeratosis. According to Mein et al. (2004), the effect of machine milking could only be responsible for 6 to $20 \%$ of the prevalence of mastitis in a dairy farm. As mastitis is a multifactorial disease, it may be that the higher number of cases of mastitis described in some farms with minimal maintenance of the milking machine (old liners, pulsation failures) or poor milking routine are also due to incorrect general practices in the farm (manure and sanitary management, animal welfare, and so on).

Based on the results of our study and those presented by our research group in Murciano-Granadina goats (Romero et al., 2017), it seems that AP in this breed could not offer any advantage over SP other than a slight reduction in milking duration in conditions of high milk flow (high milk yield, high system vacuum, and breeds with optimal milkability). In any case, the time saved for milking would always be limited in side-by-side parlors and in the presence of goats with problems or longer milking time in the same milking row. On the other hand, the installation of 4-channel pulsators for every 2 milking units or one 2-channel pulsator per milking unit, which would be mandatory to practice AP, would also increase the cost of the installation (on average 4-channel pulsators cost $20 \%$ more than 2-channel pulsators) and its maintenance, and this investment may not be justified by the minimal advantage gained.

\section{CONCLUSIONS}

Simultaneous pulsation and AP similarly affected milking fractioning, milking duration, milk yield, milk composition and teat-end status. However, SP was related to higher vacuum fluctuations in the short milk tubes than AP. Despite this fact, sanitary status of the mammary gland in both AP and SP was similar. We concluded that the use of AP in the milking of Murciano-Granadina goats provides scant improvement of the milking performance while increasing the outlay required for installation and maintenance of the milking machines.

\section{ACKNOWLEDGMENTS}

This study was supported by research Projects AGL2006-06909 [Ministerio de Educación y Ciencia of Spain, Madrid, and Fondo Europeo de Desarrollo Regional (FEDER), European Union], and AGL200910695 (Ministerio de Ciencia e Innovación of Spain, Madrid).

\section{REFERENCES}

Alejandro, M., A. Roca, G. Romero, and J. R. Díaz. 2014. Effects of overmilking and liner type and characteristics on teat tissue in small ruminants. J. Dairy Res. 81:215-222.

Ali, A. K., and G. E. Shook. 1980. An optimum transformation for somatic cell concentration in milk. J. Dairy Sci. 63:487-490.

Ambord, S., and M. Bruckmaier. 2010. Milk flow dependent vacuum loss in highline milking systems: Effects on milking characteristics and teat tissue condition. J. Dairy Sci. 93:3588-3594.

Arias, R., B. Oliete, M. Ramón, C. Arias, R. Gallego, V. Montoro, C. Gonzalo, and M. D. Pérez-Guzmán. 2012. Long-term study of environmental effects on test-day somatic cell count and milk yield in Manchega sheep. Small Rumin. Res. 106:92-97.

Besier, J., O. Lind, and R. M. Bruckmaier. 2016. Dynamics of teat-end vacuum during machine milking: types, causes and impacts on teat condition and udder health-A literature review. J. Appl. Anim. Res. 44:263-272.

Billon, P. 2004. The designing of small and medium sized milking machines for dairy sheep. Pages 28-54 in Proc. 10th Great Lakes Dairy Sheep Symposium, Eau Claire, Wisconsin. University of Wisconsin, Madison.

Billon, P., O. Sauvee, J. L. Menard, and V. Gaudin. 1998. Effects of milking and of the milking machine on somatic cells counts and intramammary infections on dairy cows. Pages 305-312 in Proc. 5th Renc. Rech. Ruminants. INRA-Institut de L'Elevage, Paris, France.

Bueso-Ródenas, J., F. M. Tangorra, G. Romero, A. Guidobono-Cavalchini, and J. R. Díaz. 2016. Effects of pulsation type (alternate and simultaneous) on mechanical milking of dairy goats (I): A study in Alpine goats varying the system vacuum level. Small Rumin. Res. 144:300-304.

Díaz, J. R., M. Alejandro, and C. Peris. 2013. Use of ultrasound scanning to estimate teat wall thickness in Murciano-Granadina goats. Livest. Sci. 155:114-122.

Díaz, J. R., C. Peris, M. Rodríguez, M. P. Molina, and N. Fernández. 2004. Effect of milking pipeline height on machine milking efficiency and milk quality in sheep. J. Dairy Sci. 87:1675-1683.

Díaz, J. R., G. Romero, R. Muelas, E. Sendra, and J. C. F. Pantoja. 2011. Influence of variation factors on electrical conductivity of milk in Murciano-Granadina goats. J. Dairy Sci. 94:3885-3894.

Gleeson, D. E., E. J. O'Callaghan, and M. V. Rath. 2004. Effect of liner design, pulsator setting, and vacuum level on bovine teat tissue changes and milking characteristics as measured by ultrasonography. Ir. Vet. J. 57:289-296.

Goetsch, A. L., S. S. Zeng, and T. A. Gipson. 2011. Factors affecting goat milk production and quality. Small Rumin. Res. 101:55-63.

Hamann, J., C. Burvenich, M. Mayntz, O. Osteras, and W. Haider. 1994. Chapter 2: Machine-induced changes in the bovine teat with respect to the new infection risk. Pages 13-22 in Machine Milking Induced Teat Tissue Reactions and New Infection Risk. Bulletin of the IDF, No. 297. Int. Dairy Fed., Brussels, Belgium.

Manzur, A., J. R. Díaz, A. Mehdid, N. Fernández, and C. Peris. 2012. Effect of mid-line or low-line milking systems on milking characteristics in goats. J. Dairy Res. 79:375-382.

McDonald, J. S., and D. A. Witzel. 1968. Vacuum fluctuation at the teat end during mechanical milking. J. Dairy Sci. 51:543-548.

Mein, G. A., D. J. Reinemann, N. Schuring, and I. Ohnstad. 2004. Milking machines and mastitis risk: A storm in a teatcup. Pages 176-188 in Proc. 43rd Annu. Mtg. National Mastitis Council, Charlotte, NC. NMC Inc., New Prague, MN.

O'Callaghan, E. J. 2004. Effects of the design of a milking unit on vacuum variations during simulated milking. Isr. J. Agric. Res. 43:237-245. 
Osterås, O., and A. Lund. 1980. The correlation between milk flow, vacuum fluctuations and decrease in vacuum in the long milk tube at the claw in different milking machines. Nord. Vet. Med. 32:281-290.

Rasmussen, M. D., E. S. Frimer, and E. L. Decker. 1994. Reverse pressure gradients across the teat canal related to machine milking. J. Dairy Sci. 77:984-993.

Rasmussen, M. D., D. J. Reinemann, and G. A. Mein. 2003. Measuring vacuum in milking machines. Pages 19-32 in IDF Bulletin 381. Int. Dairy Fed., Brussels, Belgium.

Romero, G., J. Bueso-Ródenas, P. Gascó, and J. R. Díaz. 2015. Effect of the automatic cluster removers (ACRs) in the milking of
Murciano-Granadina goats during lactation. Small Rumin. Res. 128:54-58.

Romero, G., J. Bueso-Ródenas, F. Moya, M. Alejandro, and J. R. Díaz. 2017. Short communication: Effects of pulsation type (alternate and simultaneous) on mechanical milking of dairy goats (II)- Effect of milk pipeline height on the milking efficiency and status of teat-end in Murciano-Granadina goats. Small Rumin. Res. 146:53-57.

SAS Institute Inc. 2012. SAS version 9.2. User's Guide. SAS Institute Inc., Cary, NC.

Schmidt-Madsen, P. 1975. Fluoro-opto-electronic cell counting on milk. J. Dairy Res. 42:227-239. 